\title{
In vitro cultivation of Anaplasma marginale and A. phagocytophilum in tick cell lines: a review
}

\author{
Cultivo in vitro de Anaplasma marginale e A. phagocytophilum em células de carrapatos: uma revisão \\ Lygia Maria Friche Passos ${ }^{1,2 *}$
}

${ }^{1}$ Departamento de Medicina Veterinária Preventiva, Instituto Nacional em Ciência e Tecnologia - Informação Genético-Sanitária da
Pecuária Brasileira - INCT, Escola de Veterinária, Universidade Federal de Minas Gerais - UFMG, Belo Horizonte, MG, Brasil

Pecuária Brasileira - INCT, Escola de Veterinánia, Universidade Federal de Minas Gerais - UFMG, Belo Horizonte, MG, Brasil

${ }^{2}$ Institute for Comparative Tropical Medicine and Parasitology, Ludwig-Maximilians-Universitaet Muenchen - LMU, Germany

Received March 12, 2012

Accepted May 16, 2012

\begin{abstract}
Continuous cell lines have been established from several ixodid and argasid tick species, representing an excellent tool suitable for the isolation of pathogens and their subsequent propagation, which in turn allows the production of antigenic material for diagnostic tests, antibody and vaccine production, and also for studies on host-vector-pathogen relationships. This paper reviews the use of tick cells for culture initiation and maintenance of two obligate intracellular bacterial pathogens, Anaplasma marginale and Anaplasma phagocytophilum. These in vitro cultivation systems have been used in a wide range of studies, covering morphological ultrastructural analysis, genetics, proteomics and biological differences between strains, including genome transcriptional and protein expression approaches, enabling comparisons between host and vector cells. Thus, such systems open a new window for a better understanding of interactions between pathogens and tick cells. Last but not least, such systems contribute to the reduction in usage of animals for experimental research, as antigenic material can be produced in reasonably large quantities without the use of in vivo species-specific systems.
\end{abstract}

Keywords: Tick cells, Anaplasma marginale, Anaplasma phagocytophilum, in vitro culture, review.

\section{Resumo}

Linhagens contínuas de células já foram estabelecidas a partir de várias espécies de carrapatos ixodídeos e argasídeos e representam uma ferramenta excelente para o isolamento e propagaçáo de patógenos, permitindo a produção de material antigênico para testes diagnósticos, produção de anticorpos e vacinas, e também para estudos das relaçóes entre hospedeiro-vetor-patógenos. Este artigo revisa o uso de células de carrapatos para estabelecimento e manutenção in vitro de dois patógenos intracelulares, Anaplasma marginale e Anaplasma phagocytophilum. Estes sistemas de cultivo in vitro, têm sido utilizados em vários estudos, tais como análises morfológicas, genéticas, proteômicas e estudos diferenciais entre isolados, incluindo genômica transcricional e expressóes proteicas, permitindo comparaçóes entre células dos hospedeiros e dos vetores. Tais sistemas constituem, portanto, uma nova abordagem para melhor entendimento das relaçôes entre patógenos e células de carrapatos. Além disso, tais sistemas contribuem para a redução do uso de animais de experimentação, uma vez que permitem a produção de grandes quantidades de material antigênico sem o uso de sistemas espécie-específicos in vivo.

Palavras-chave: Células de carrapatos, Anaplasma marginale, Anaplasma phagocytophilum, cultivo in vitro, revisão.

\section{Introduction}

Although more than 800 tick species have been identified worldwide (NAVA et al., 2009), relatively few species have yielded cell lines to date. The first continuous tick cell lines were established in 1975 (VARMA et al., 1975) and since then, the

*Corresponding author: Lygia Maria Friche Passos Departamento de Medicina Veterinaria Preventiva,

Universidade Federal de Minas Gerais - UFMG,

Av. Antônio Carlos 6627, CEP 30123-970, Belo Horizonte, MG, Brasil

e-mail: lygia.passos@lmu.de; lygia@vet.ufmg.br number of established cell lines has increased to over 50, derived from both ixodid and argasid species (Table 1).

Most tick cell lines were established from embryonic cells and grow three-dimensionally in specifically devised culture media under a normal atmosphere; incubation temperatures vary between 28 and $34^{\circ} \mathrm{C}$ (BELL-SAKYI et al., 2007, 2009; MATTILA et al., 2007; MUNDERLOH et al., 1994). Normally more than one cell type is present in a culture; no tick cell clones have been reported thus far. Some cell lines grow relatively slowly and require less regular subcultures. 
Table 1. Tick cell lines currently available.

\begin{tabular}{|c|c|c|c|}
\hline Tick species (ixodid) & No of cell lines & Source* & References \\
\hline Amblyomma americanum & 2 & UM & Kurtti et al.(2005) \\
\hline Amblyomma variegatum & 2 & UE & Bell-Sakyi et al. (2000) and Bell-Sakyi (2004) \\
\hline Rhipicephalus (Boophilus) decoloratus & 3 & UE & Bell-Sakyi (2004) and Lallinger et al. ( 2010) \\
\hline Rhipicephalus (Boophilus) microplus & 9 & UE, UM, TAM & $\begin{array}{l}\text { Bell-Sakyi (2004), Bell-Sakyi et al. (2007), Holman } \\
\text { (1981) and Bell-Sakyi (personal communication) }\end{array}$ \\
\hline Dermacentor albipictus & 1 & UM & Policastro et al. (1997) \\
\hline Dermacentor andersoni & 3 & UM & Kurtti et al.(2005) and Simser et al. (2001) \\
\hline Dermacentor (Anocentor) nitens & 1 & UM & Kurtti et al. (1983) \\
\hline Dermacentor variabilis & 1 & UM & Kurtti et al.(2005) and Yunker et al. (1981) \\
\hline Hyalomma anatolicum anatolicum & 5 & UE & Bell-Sakyi (1991) \\
\hline Ixodes scapularis & 7 & UM & Munderloh et al. (1994) \\
\hline Ixodes ricinus & 4 & UE, UM & Bell-Sakyi et al. (2007) and Simser et al.(2002) \\
\hline Rhipicephalus appendiculatus & 5 & UE, UM, LSHTM & $\begin{array}{l}\text { Bekker et al. (2002) and Bell-Sakyi (2004), Kurtti and } \\
\text { Munderloh (1982) and Varma et al. (1975) }\end{array}$ \\
\hline Rhipicephalus evertsi & 2 & UE & Bell-Sakyi (personal communication) \\
\hline Rhipicephalus sanguineus & 1 & UM & Kurtti and Munderloh (1982) \\
\hline \multicolumn{4}{|l|}{ Tick species (argasid) } \\
\hline Carios capensis & 4 & UM & Mattila et al. (2007) \\
\hline Ornithodoros moubata & 6 & UE & Bell-Sakyi et al. (2009) \\
\hline Total & 56 & & \\
\hline
\end{tabular}

*UM = University of Minnesota (Kurtti and Munderloh). UE = University of Edinburgh (Bell-Sakyi) The Roslin Wellcome Trust Tick Cell Biobank http://tickcells.roslin.ac.uk. TAM = Texas A\&M University (Holman). LSHTM = London School of Hygiene and Tropical Medicine (VARMA et al., 1975).

Cryopreservation of tick cells in liquid nitrogen can be difficult; however, some cell lines can be preserved under refrigeration for up to one month (BASTOS et al., 2006; LALLINGER et al., 2010).

Several bacterial genera, notably Anaplasma, Ehrlichia, Borrelia and Rickettsia, and numerous arboviruses have been propagated in tick cell cultures (BELL-SAKYI et al., 2007). And recently even the protozoan Babesia bigemina has been reported to infect and multiply in a tick cell line (RIBEIRO et al., 2009). Thus the increasing application of tick cell lines to study a range of infectious agents has a huge potential for provision of antigenic material from specific tick stages in large quantities and without the use of experimental animals.

\section{Culture Initiation and Propagation of Anaplasma marginale}

Bovine anaplasmosis, caused by the intraerythrocytic rickettsia Anaplasma marginale, is a tick-transmitted disease characterized by anemia, weight loss, fever, abortion and death, leading to significant economic losses for dairy and beef producers (WANDURAGALA; RISTIC, 1993). After recovering from acute disease, animals develop a persistent infection characterized by low level, chronic rickettsemia (KIESER et al., 1990), acting as a source of infection for other animals within the herd or the geographic area.

First attempts to propagate $A$. marginale were limited to the erythrocytic stage, using a whole-blood culture system based on a method used for Plasmodium (KESSLER et al., 1979), and did not result in continuous propagation. Another attempt to cultivate $A$. marginale was based on infection of arthropod cell lines derived from mosquitoes, but again propagation did not occur (MAZZOLA et al., 1976). Later, the first attempt to infect a tick cell line derived from Dermacentor variabilis (RML-15) was reported (SAMISH et al., 1988), with numerous groups of Anaplasma-like particles being seen in the tick cell cytoplasm; however, after one passage a continuous culture was not established.

The major advance in cultivation of $A$. marginale was achieved in the mid-1990s with the tick cell line IDE8, derived from embryonic Ixodes scapularis ticks (MUNDERLOH et al., 1994), and since then this system has been successfully used to propagate isolates of A. marginale in the United States (MUNDERLOH et al., 1996; BLOUIN; KOCAN, 1998; BLOUIN et al., 2000) and South Africa (ZWEYGARTH et al., 2006). Recently, a Brazilian isolate of A. marginale (UFMG1, GenBank accession number EU676176), morphologically distinct from other cultured isolates due to the presence of an inclusion appendage (RIBEIRO et al., 1997), has been successfully established in IDE8 cells (BASTOS et al., 2009), although this isolate was shown not to infect Rhipicephalus (Boophilus) microplus ticks (RUIZ et al., 2005). Interestingly, the same isolate infected a cell line derived from $R$. (B.) microplus ticks (ESTEVES et al., 2009).

A. marginale cultures can be initiated from blood obtained from infected calves during ascending rickettsemia (BLOUIN et al., 2000; BASTOS et al., 2009). Blood samples are collected with anticoagulant, and usually the blood cells are washed and subsequently cryopreserved in liquid nitrogen using DMSO as cryoprotectant. IDE8 cells are cultured in L-15B medium supplemented with various additives, following standard procedures (MUNDERLOH et al., 1994). Culture flasks containing growing layers of IDE8 cells can be infected with $A$. marginale 
cryostabilates. After defrosting the blood stabilates by immersion in a $37^{\circ} \mathrm{C}$ water bath, the content of the cryovials is centrifuged $(10,000 \times g$, for 20 minutes $)$ and the pelleted erythrocytes are resuspended in a complete culture medium which is suitable for the propagation of $A$. marginale (MUNDERLOH et al., 1996). Inoculated flasks are incubated at $34^{\circ} \mathrm{C}$ and the first medium change can be carried out 24 hours after inoculation, whereas subsequent medium changes are done weekly. The cultures should be monitored by direct examination under an inverted microscope and/or by microscopic examination of Giemsa-stained cytocentrifuge smears (Figure 1).

Initially, well defined parasitophorous vacuoles containing compact colonies are formed; subsequently, approximately two weeks later, large colonies are observed and their contents are released into the culture medium after disruption of the vacuole membrane. A. marginale-infected cells can be propagated continuously, and infection rates can reach up to $80 \%$.

A. marginale bacteria can be quantified and used as antigenic material for diagnostic tests or for immunization trials (GARCIAGARCIA et al., 2004; BASTOS et al., 2010). And almost importantly, it has been shown that cultured $A$. marginale strains retain their antigenic properties and infectivity for cattle after successive passages (MUNDERLOH et al., 1996; BLOUIN; KOCAN, 1998; BARBET et al., 1999).

This in vitro culture system has opened a new window for studies of pathogen-host cell interactions under controlled conditions, allowing comparative in vitro/ in vivo studies on cell attachment, invasion and intracellular development of $A$. marginale, as well as the development of infection-inhibition and ELISA-based screening assays for evaluation of bacteria growth and infection levels (BLOUIN et al., 2003).

In addition, in vitro cultivation of $A$. marginale in tick cells has been used in comparative studies with infected bovine erythrocytes for differential bacterial gene transcriptional analyses and expression profile of outer membrane proteins to search for potential $A$. marginale vaccine candidates (BRAYTON et al., 2006; GARCIA-GARCIA et al., 2004; NOH et al., 2006), and

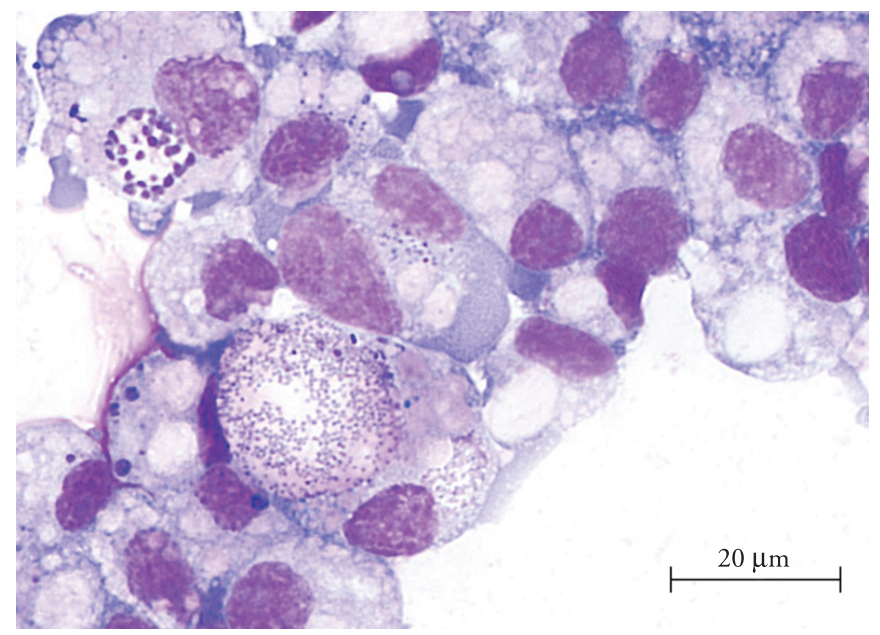

Figure 1. Photomicrograph of a Giemsa-stained cytocentrifuge smear of IDE8 cells infected with Anaplasma marginale. in RNA interference approaches for functional studies to discover genes/proteins that are differentially expressed in tick cells in response to infection with $A$. marginale (DE LA FUENTE et al., 2007; KOCAN et al., 2009). These studies indicate that $A$. marginale affects the expression of tick genes important for tick survival and pathogen multiplication; thus, a molecular mechanism occurs by which tick cell gene expression mediates the development of the pathogen through ticks.

\section{Culture Initiation and Propagation of Anaplasma phagocytophilum}

Anaplasma phagocytophilum, a tick-transmitted gram-negative bacterium, is an emerging zoonotic infection, transmitted by ixodid ticks (PAROLA et al., 2005). Since its first discovery in Scotland in 1932, the microorganism has gained more and more attention in veterinary medicine as the agent of tick-borne fever in ruminants and granulocytic anaplasmosis in a wide variety of domestic animals, such as dogs, cats, and horses (WOLDEHIWET, 2010). Humans are accidental hosts (PAROLA et al., 2005; CARRADE et al., 2009) and the severity of the so-called human granulocytic anaplasmosis (HGA) ranges from mild to more serious infections and in rare cases even death. The enzootic cycle includes rodents (BOWN et al., 2003) and possibly birds (BJOERSDORFF et al., 2001) as reservoir hosts.

Successful initiation and maintenance of $A$. phagocytophilum in the I. scapularis tick cell lines IDE8 and/or ISE6 has been reported (MUNDERLOH et al., 1996; WOLDEHIWET et al., 2002). Although tick cell lines are not routinely used for direct isolation of $A$. phagocytophilum, it was shown that organisms derived from infected HL60 cells can invade and grow in tick cell cultures (MUNDERLOH et al., 1999).

Very recently several European isolates of $A$. phagocytophilum were established in IDE8 tick cells (ZWEYGARTH et al., 2010, 2011); these include isolates derived from horses, dogs and one isolate derived from roe deer, which has been preliminary characterized (SILAGHI et al., 2011) (Table 2). Cultures are initiated by adding infected granulocytes from venous blood of infected animals into tick cell cultures. Whole blood (WOLDEHIWET et al., 2002), washed buffy coat cells (MUNDERLOH et al., 1999) or white blood cells after hypotonic lysis of the erythrocytes (MUNDERLOH et al., 1996; ZWEYGARTH et al., 2010) can be used for initiation. Culture propagation is basically the same as with $A$. marginale, including culture medium and incubation temperature.

In vitro cultivation of $A$. phagocytophilum in tick cells has been used for a wide range of studies and applications, from morphological ultrastructural analyses of geographical variant strains to investigations on susceptibility of strains to antibiotics and neutralizing effects of immune serum (WOLDEHIWET, 2010). For example, recently the ISE6 cell line has been used for isolation of variants of $A$. phagocytophilum directly from ticks (MASSUNG et al., 2007), representing a new tool for studies on genetics, proteomics and biological differences amongst strains differing in infectivity for mice and humans. This in vitro system has also been useful for the comparisons of genome transcriptional and protein expression from vertebrate and tick 
Table 2. Anaplasma phagocytophilum established in tick cell cultures.

\begin{tabular}{cccc}
\hline Mammalian host & Tick cell line(s) & Country of origin & Reference \\
\hline Sheep & ISE6, IDE8 & UK & Woldehiwet et al. (2002) \\
\hline $\begin{array}{c}\text { Dog, Horse } \\
\text { Human (HL60 culture derived) }\end{array}$ & ISE6 & USA & Munderloh et al. (1996, 1999) \\
\hline $\begin{array}{c}\text { Dog } \\
\text { Horse }\end{array}$ & IDE8 & $\begin{array}{c}\text { Germany, Spain and } \\
\text { Switzerland }\end{array}$ & $\begin{array}{c}\text { Zweygarth et al. (2010, 2011) } \\
\text { Silaghi et al. (2011) }\end{array}$ \\
\hline
\end{tabular}

cells (JAURON et al., 2001), and the generation of the whole genome transcript profiling for $A$. phagocytophilum by tiling array assays (NELSON et al., 2008).

A recent study comparing tick cell gene expression profiles in response to $A$. phogocytophilum and $A$. marginale infection by microarray and real-time RT-PCR analyses indicated differential gene expression, possibly related to differences in the life cycle of the two pathogens in ticks (ZIVKOVIC et al., 2009). However, despite the tremendous impact of cultivation of tick cells on tick research, differences in expression patterns indicate that in vitro studies should be corroborated with in vivo studies (DE LA FUENTE et al., 2010).

\section{Final Remarks}

Tick cell in vitro systems constitute a good source of tick-stage antigenic material, with a huge potential for development of improved vaccines and diagnostic assays, particularly in tropical areas where Anaplasma infections are endemic and the maintenance of animal donors free from hemoparasites is difficult and expensive. In addition, they provide a useful model system for studies such as molecular analysis, gene transcription, cellular and molecular relationships among pathogens and vectors, and comparative in vitrol in vivo studies.

\section{Acknowledgements}

The author thanks Dr Erich Zweygarth and Dr Lesley Bell-Sakyi for critically revising the manuscript and Ms H. Schöl for photographic technical support.

\section{References}

Barbet AF, Blentlinger R, Yi J, Lundgren AM, Blouin EF, Kocan KM. Comparison of surface proteins of Anaplasma marginale grown in tick cell culture, tick salivary glands, and cattle. Infect Immun 1999; 67(1): 102-107. PMid:9864202 PMCid:96283.

Bastos CV, Passos LM, Facury-Filho EJ, Rabelo EM, De La Fuente J, Ribeiro MFB. Protection in the absence of exclusion between two Brazilian isolates of Anaplasma marginale in experimentally infected calves. Vet J 2010; 186(3): 374-378. PMid:19837622. http://dx.doi. org/10.1016/j.tvjl.2009.09.013

Bastos CV, Passos LMF, Vasconcelos MMC, Ribeiro MFB. In vitro establishment and propagation of a Brazilian strain of Anaplasma marginale with appendage in IDE8 (Ixodes scapularis) cells. Braz J
Microbiol 2009; 40(2): 399-403. http://dx.doi.org/10.1590/S151783822009000200034

Bastos CV, Vasconcelos MMC, Ribeiro MFB, Passos LMF. Use of refrigeration as a practical means to preserve viability of in vitro-cultured IDE8 cells. Exp Appl Acarol 2006; 39(3-4): 347-352. PMid:16779573. http://dx.doi.org/10.1007/s10493-006-9006-5

Bekker CP, Bell-Sakyi L, Paxton EA, Martinez D, Bensaid A, Jongejan, F. Transcriptional analysis of the major antigenic protein 1 multigene family of Cowdria ruminantium. Gene 2002; 285(1-2): 193-201. http:// dx.doi.org/10.1016/S0378-1119(02)00408-0

Bell-Sakyi L. Continuous cell lines from the tick Hyalomma anatolicum anatolicum. J Parasitol 1991; 77(6): 1006-1008. PMid:1779279. http:// dx.doi.org/10.2307/3282757

Bell-Sakyi L. Ehrlichia ruminantium grows in cell lines from four ixodid tick genera. J Comp Pathol 2004; 130(4): 285-293. PMid:15053931. http://dx.doi.org/10.1016/j.jcpa.2003.12.002

Bell-Sakyi L, Paxton EA, Munderloh UG, Sumption KJ. Growth of Cowdria ruminantium, the causative agent of heartwater, in a tick cell line. J Clin Microbiol 2000; 38(3): 1238-1240. PMid:10699030 PMCid:86386.

Bell-Sakyi L, Ruzek D, Gould EA. Cell lines from the soft tick Ornithodoros moubata. Exp Appl Acarol 2009; 49(3): 209-219. PMid:19252822 PMCid:2755799. http://dx.doi.org/10.1007/s10493009-9258-y

Bell-Sakyi L, Zweygarth E, Blouin EF, Gould EA, Jongejan F. Tick cell lines: tools for tick and tick-borne disease research. Trends Parasitol 2007; 23(9): 450-457. PMid:17662657. http://dx.doi. org/10.1016/j.pt.2007.07.009

Bjoersdorff A, Bergstrom S, Massung RF, Haemig PD, Olsen B. Ehrlichiainfected ticks on migrating birds. Emerg Infect Dis 2001; 7(5): 877-879. PMid:11747702 PMCid:2631880.

Blouin EF, Kocan KM. Morphology and development of Anaplasma marginale (Rickettsiales: Anaplasmataceae) in cultured Ixodes scapularis (Acari: Ixodidae) cells. J Med Entomol 1998; 35(5): 788-797. PMid:9775610.

Blouin EF, Barbet AF, Yi J, Kocan KM, Saliki JT. Establishment and characterization of an Oklahoma isolate of Anaplasma marginale in cultured Ixodes scapularis cells. Vet Parasitol 2000; 87(4): 301-313. http:// dx.doi.org/10.1016/S0304-4017(99)00183-1

Blouin EF, Saliki JT, De La Fuente J, Garcia-Garcia JC, Kocan KM. Antibodies to Anaplasma marginale major surface proteins $1 \mathrm{a}$ and $1 \mathrm{~b}$ inhibit infectivity for cultured tick cells. Vet Parasitol 2003; 111(2-3): 247-260. http://dx.doi.org/10.1016/S0304-4017(02)00378-3

Bown KJ, Begon M, Bennet M, Woldehiwet Z, Ogden NH. Seasonal dynamics of Anaplasma phagocytophila in a rodent-tick (Ixodes trianguliceps) 
system, United Kingdom. Emerg Infect Dis 2003; 9(1): 63-70. PMid:12533283 PMCid:2873734.

Brayton KA, Palmer GH, Brown WC. Genomic and proteomic approaches to vaccine candidate identification for Anaplasma marginale. Expert Rev Vaccines 2006; 5(1): 95-101. PMid:16451111. http://dx.doi. org/10.1586/14760584.5.1.95

Carrade DD, Foley JE, Borjesson DL, Sykes JE. Canine granulocytic anaplasmosis: a review. J Vet Intern Med 2009; 23(6): 1129-1141. PMid:19761477. http://dx.doi.org/10.1111/j.1939-1676.2009.0384.x

De La Fuente J, Blouin EF, Manzano-Roman R, Naranjo V, Almazán C, Pérez De La Lastra JM, et al. Functional genomic studies of tick cells in response to infection with the cattle pathogen, Anaplasma marginale. Genomics 2007; 90(6): 712-722. PMid:17964755. http://dx.doi. org/10.1016/j.ygeno.2007.08.009

De La Fuente J, Kocan KM, Blouin EF, Zivkovic Z, Naranjo V, Almazán $\mathrm{C}$, et al. Functional genomics and evolution of tick-Anaplasma interactions and vaccine development. Vet Parasitol 2010; 167(2-4): 175-186. PMid:19819630. http://dx.doi.org/10.1016/j.vetpar.2009.09.019

Esteves E, Bastos CV, Zivkovic Z, De La Fuente J, Kocan K, Blouin E, et al. Propagation of a Brazilian isolate of Anaplasma marginale with appendage in a tick cell line (BME26) derived from Rhipicephalus (Boophilus) microplus. Vet Parasitol 2009; 161(1-2): 150-153. PMid:19150177. http://dx.doi.org/10.1016/j.vetpar.2008.12.006

Garcia-Garcia JC, De La Fuente J, Blouin EF, Johnson TJ, Halbur $\mathrm{T}$, Onet VC, et al. Differential expression of the mspl $\alpha$ gene of Anaplasma marginale occurs in bovine erythrocytes and tick cells. Vet Microbiol 2004; 98(3-4): 261-272. PMid:15036535. http://dx.doi. org/10.1016/j.vetmic.2003.10.021

Holman PJ. Partial characterization of a unique female diploid cell strain from the tick Boophilus microplus (Acari: Ixodidae). $J$ Med Entomol 1981; 18(11): 84-88. PMid:7288834.

Jauron SD, Nelson CM, Fingerle V, Ravyn MD, Goodman JL, Johnson RC, et al. Host cell-specific expression of a p44 epitope by the human granulocytic ehrlichiosis agent. J Infect Dis 2001; 184(11): 1445-1450. PMid:11709787. http://dx.doi.org/10.1086/324428

Kessler RH, Ristic M, Sells DM, Carson CA. In-vitro cultivation of Anaplasma marginale: growth pattern and morphologic appearance. Am J Vet Res 1979; 40(12): 1767-1773. PMid:230766.

Kieser ST, Eriks IS, Palmer GH. Cyclic rickettsemia during persistent Anaplasma marginale infection of cattle. Infect Immun 1990; 58(4): 1117-119. PMid:2318532 PMCid:258591.

Kocan KM, Zivkovic Z, Blouin EF, Naranjo V, Almazán C, Mitra R, et al. Silencing of genes involved in Anaplasma marginale-tick interactions affects the pathogen developmental cycle in Dermacentor variabilis. BMC Dev Biol 2009; 9: 42. PMid:19607704 PMCid:2714835. http://dx.doi. org/10.1186/1471-213X-9-42

Kurtti TJ, Munderloh UG. Tick cell culture: characteristics, growth requirements and applications to parasitology. In: Maramorosch K, Mitsuhashi J. Invertebrate cell culture applications. Academic press: New York; 1982. p. 195-232.

Kurtti TJ, Munderloh UG, Stiller D. The interaction of Babesia caballi kinetes with tick cells. J Invertebr Pathol 1983; 42(3): 334-343. http:// dx.doi.org/10.1016/0022-2011(83)90172-6

Kurtti TJ, Simser JA, Baldridge GD, Palmer AT, Munderloh UG. Factors influencing in vitro infectivity and growth of Rickettsia peacockii (Rickettsiales: Rickettsiaceae), an endosymbiont of the Rocky Mountain wood tick, Dermacentor andersoni (Acari, Ixodidae). J Invertebr Pathol 2005; 90(3): 177-186. PMid:16288906 PMCid:1625098. http:// dx.doi.org/10.1016/j.jip.2005.09.001

Lallinger G, Zweygarth E, Bell-Sakyi L, Passos LMF. Cold storage and cryopreservation of tick cell lines. Parasit Vectors 2010; 3(1): 37. http:// dx.doi.org/10.1186/1756-3305-3-37

Massung RF, Levin ML, Munderloh UG, Silverman DJ, Lynch MJ, Gaywee JK, et al. Isolation and propagation of the Ap-variant 1 strain of Anaplasma phagocytophilum in a tick cell line. J Clin Microbiol 2007; 45(7): 2138-2143. PMid:17475757 PMCid:1932999. http://dx.doi.org/10.1128/JCM.00478-07

Mattila JT, Burkhardt NY, Hutcheson J, Munderloh UG, Kurtti TJ. Isolation of cell lines and a rickettsial endosymbiont from the soft tick Carios capensis (Acari: Argasidae: Ornithodorinae). J Med Entomol 2007; 44(6): 1091-1101. http://dx.doi.org/10.1603/00222585(2007)44[1091:IOCLAA]2.0.CO;2

Mazzola V, Amerault TE, Roby TO. Survival of Anaplasma marginale in Aedes albopictus cells. Am J Vet Res 1976; 37(8): 987-989. PMid:949127.

Munderloh UG, Liu Y, Wang M, Chen C, Kurtti TJ. Establishment, maintenance and description of cell lines from the tick Ixodes scapularis. J Parasitol 1994; 80(4): 533-543. PMid:8064520. http://dx.doi. org/10.2307/3283188

Munderloh UG, Blouin EF, Kocan KM, Ge NL, Edwards WL, Kurtti TJ. Establishment of the tick (Acari: Ixodidae)-borne cattle pathogen Anaplasma marginale (Rickettsiales: Anaplasmataceae) in tick cell culture. J Med Entomol 1996; 33(4): 656-664. PMid:8699463.

Munderloh UG, Jauron SD, Fingerle V, Leitritz L, Hayes SF, Hautman JM, et al. Invasion and intracellular development of the human granulocytic ehrlichiosis agent in tick cell culture. J Clin Microbiol 1999; 37(8): 2518-2524. PMid:10405394 PMCid:85271.

Nava S, Guglielmone AA, Mangold AJ. An overview of systematics and evolution of ticks. Front Biosci 2009; 14: 2857-2877. PMid:19273240. http://dx.doi.org/10.2741/3418

Nelson CM, Herron MJ, Felsheim RF, Schloeder BR, Grindle SM, Chavez AO, et al. Whole genome transcription profiling of Anaplasma phagocytophilum in human and tick host cells by tiling array analysis. BMC Genomics 2008; 9: 364. PMid:18671858 PMCid:2527338. http:// dx.doi.org/10.1186/1471-2164-9-364

Noh SM, Brayton KA, Knowles DP, Agnes JT, Dark MJ, Brown WC, et al. Differential expression and sequence conservation of the Anaplasma marginale $m s p 2$ gene superfamily outer membrane proteins. Infect Immun 2006; 74(6): 3471-3479. PMid:16714578 PMCid:1479288. http://dx.doi.org/10.1128/IAI.01843-05

Parola P, Davoust B, Raoult D. Tick- and flea-borne rickettsial emerging zoonoses. Vet Res 2005; 36(3): 469-92. PMid:15845235. http://dx.doi. org/10.1051/vetres:2005004

Policastro PF, Munderloh UG, Fischer ER, Hackstadt T. Rickettsia rickettsii growth and temperature-inducible protein expression in embryonic tick cell lines. J Med Microbiol 1997; 46(10): 839-845. PMid:9364140. http://dx.doi.org/10.1099/00222615-46-10-839

Ribeiro MFB, Bastos CV, Vasconcelos MMC, Passos LMF. Babesia bigemina: in vitro multiplication of sporokinetes in Ixodes scapularis (IDE8) cells. Exp Parasitol 2009; 122(3): 192-195. PMid:19324040. http://dx.doi.org/10.1016/j.exppara.2009.03.011

Ribeiro MFB, Passos LMF, Guimarães AM. Ultrastructure of Anaplasma marginale with an inclusion appendage, isolated in Minas Gerais State, 
Brazil. Vet Parasitol 1997; 70(4): 271-277. http://dx.doi.org/10.1016/ S0304-4017(97)00004-6

Ruiz PMG, Passos LMF, Ribeiro MFB. Lack of infectivity of a Brazilian Anaplasma marginale isolate for Boophilus microplus ticks. Vet Parasitol 2005; 128(3-4): 325-31. PMid:15740870. http://dx.doi. org/10.1016/j.vetpar.2004.11.017

Samish M, Pipano E, Hana B. Cultivation of Anaplasma marginale from cattle in a Dermacentor cell line. Am J Vet Res 1988; 49(2): 254-256. PMid:3348535.

Simser JA, Palmer AT, Fingerle V, Wilske B, Kurtti TJ, Munderloh UG. Rickettsia monacensis sp. nov., a spotted fever group Rickettsia, from ticks (Ixodes ricinus) collected in a European city park. Appl Environ Microbiol 2002; 68(9): 4559-4566. PMid:12200314 PMCid:124077. http://dx.doi.org/10.1128/AEM.68.9.4559-4566.2002

Simser JA, Palmer AT, Munderloh UG, Kurtti TJ. Isolation of a spotted fever group Rickettsia, Rickettsia peacockii, in a Rocky Mountain wood tick, Dermacentor andersoni, cell line. Appl Environ Microbiol2001; 67(2): 546-552. PMid:11157215 PMCid:92619. http:// dx.doi.org/10.1128/AEM.67.2.546-552.2001

Silaghi C, Kauffmann M, Passos LMF, Pfister K, Zweygarth E. Isolation, propagation and preliminary characterisation of Anaplasma phagocytophilum from roe deer (Capreolus capreolus) in the tick cell line IDE8. Ticks Tick Borne Dis 2011; 2(4): 204-8. PMid:22108013. http:// dx.doi.org/10.1016/j.ttbdis.2011.09.002

Varma MG, Pudney M, Leake CJ. The establishment of three cell lines from the tick Rhipicephalus appendiculatus (Acari: Ixodidae) and their infection with some arboviruses. J Med Entomol 1975; 11(6): 698-706. PMid:1123829.
Wanduragala L, Ristic M. Anaplasmosis. In: Woldehiwet Z, Ristic M. Rickettsial and chlamydial diseases of domestic animals. Oxford: Pergamon Press; 1993. p. 65-88.

Woldehiwet Z. The natural history of Anaplasma phagocytophilum. Vet Parasitol 2010; 167(2-4): 108-122. PMid:19811878. http://dx.doi. org/10.1016/j.vetpar.2009.09.013

Woldehiwet Z, Horrocks BK, Scaife H, Ross G, Munderloh UG, Bown, $\mathrm{K}$ et al. Cultivation of an ovine strain of Ehrlichia phagocytophila in tick cell cultures. J Comp Pathol 2002; 127(2-3): 142-149. PMid:12354525. http://dx.doi.org/10.1053/jcpa.2002.0574

Yunker CE, Cory J, Meibos H. Continuous cell lines from embryonic tissues of ticks (Acari: Ixodidae). In Vitro Cell. Dev. Biol. Plant 1981; 17(2): 139-142. PMid:7275139. http://dx.doi.org/10.1007/BF02618071

Zivkovic Z, Blouin EF, Manzano-Roman R, Almazán C, Naranjo V, Massung RF. Anaplasma phagocytophilum and Anaplasma marginale elicit different gene expression responses in cultured tick cells. Comp Funct Genomics 2009; 2009: 25-33.

Zweygarth E, Josemans AI, Spickett AM, Steyn HC, Putterill J, Troskie PC, et al. In vitro cultivation of a South African isolate of an Anaplasma sp. in tick cell cultures. Onderstepoort J Vet Res 2006; 73(4): 251-255. PMid:17283724.

Zweygarth E, Schöl H, Passos LMF, Pfister K. In vitro establishment of equine and canine Anaplasma phagocytophilum isolates in tick cells. In: DVG-Fachgruppentagung Parasitologie und parasitäre Krankheiten, 2010 Munich. Tierärztl Prax 38, A20 2010.

Zweygarth E, Schöl H, Lis K, Pfister K, Passos LMF. In vitro culture of European Anaplasma phagocytophilum isolates in tick cells. In: 7th Ticks and Tick-borne Pathogens International Conference, 28. August - 2. September 2011, Zaragoza, Spain 2011. 